\title{
A didactic approach for quantification of diazepam tablets by UV spectrophotometry
}

\section{Uma abordagem didática para a quantificação de comprimidos de diazepam por espectroscopia de UV}

\author{
Patrícia Rijo $^{1,2}$, Lara Ribeiro ${ }^{3}$, Ana Sofia Fernandes ${ }^{1,2}$, Célia faustino² \\ ${ }^{1}$ CBIOS - Universidade Lusófona's Research Center for Biosciences and Health Technologies (UDE), Campo Grande 376, \\ 1749-024, Lisboa, Portugal \\ ${ }^{2}$ Instituto de Investigação do Medicamento (iMed.ULisboa), Faculdade de Farmácia, Universidade de Lisboa, Av. Prof. \\ Gama Pinto, 1649-003 Lisboa, Portugal \\ ${ }^{3}$ Centro de Química e Bioquímica (CQB), Faculdade de Ciências da Universidade de Lisboa, Campo Grande, 1749-016 \\ Lisboa, Portugal \\ Email: patricia.rijo@ulusofona.pt
}

\begin{abstract}
The present paper describes a simple laboratory procedure for the quantification of diazepam, a central nervous system depressant benzodiazepine, by ultraviolet spectroscopy. Standard solutions of diazepam, prepared from a stock solution, were used to construct a calibration curve. Commercial tablets of diazepam were then analysed and the results obtained were in accordance with the expected percentage range of the manufacturer's claim and with the specifications of the Portuguese Pharmacopeia.
\end{abstract}

Keywords: Diazepam tablets; UV Spectroscopy; laboratory class

\begin{abstract}
Resumo
O presente artigo descreve um método laboratorial simples para a quantificação de diazepam, uma benzodiazepina depressora do sistema nervoso central, por espectroscopia de ultravioleta. Utilizaram-se soluções padrão de diazepam, preparadas a partir de uma solução stock, para construir a curva de calibração. Analisaram-se então comprimidos comerciais de diazepam e os resultados obtidos foram de acordo com o esperado tendo em conta a dosagem indicada e as especificações da farmacopeia portuguesa (2).
\end{abstract}

Palavras-chave: Comprimidos de Diazepam, Espectroscopia UV, aula laboratorial 


\section{Introduction}

Ultraviolet spectroscopy is a simple and powerful technique commonly used in pharmaceutical analysis despite the widespread use of high performance liquid chromatography (1). This analytical tool is relevant in the pharmaceutical industry in areas such as quality control (2). Therefore, students of Pharmaceutical Sciences need to be familiar with this methodology (3-11). In this regard, this paper was designed to introduce the technique of ultraviolet spectroscopy to undergraduate students attending Pharmaceutical Organic Chemistry classes and describes a simple laboratory procedure for the quantitative assay of diazepam, a central nervous system depressant benzodiazepine, in commercial tablets.

Benzodiazepines are among the most commonly prescribed drugs worldwide, being used mainly for the treatment of anxiety disorders and insomnia. These drugs are central nervous system depressants with sedative-hypnotic, muscle-relaxant, anxiolytic and anticonvulsant effects (12). Diazepam (Figure 1) is a white or light yellow crystalline powder, only slightly soluble in water but soluble in dichloromethane and ethanol.

\section{Introdução}

A espectroscopia de ultravioleta é uma técnica simples, exequível e robusta que ainda é largamente utilizada em análises farmacêuticas, apesar da utilização generalizada da cromatografia líquida de alta eficiência (1). Esta ferramenta analítica é útil na indústria farmacêutica em áreas como o controlo de qualidade (2). É assim fundamental que os estudantes de Ciências Farmacêuticas estejam familiarizados com esta metodologia (3-11). Neste sentido, este trabalho foi concebido para introduzir a técnica de espectroscopia de ultravioleta a estudantes que frequentam aulas de Química Orgânica Farmacêutica e descreve um procedimento laboratorial simples para o ensaio quantitativo de diazepam, uma benzodiazepina depressora do sistema nervoso central, em comprimidos comerciais.

As benzodiazepinas estão entre os fármacos mais prescritos em todo o mundo, sendo utilizadas principalmente para o tratamento de ansiedade e insônia. Estes fármacos são depressores do sistema nervoso central com efeitos sedativo-hipnóticos, relaxantes musculares, ansiolíticos e anticonvulsivos (12). O diazepam (Figura 1) é um pó cristalino branco ou amarelo claro, apenas ligeiramente solúvel em água mas solúvel em diclorometano e etanol.<smiles>CN1C(=O)CN=C(c2ccccc2)c2cc(Cl)ccc21</smiles>

Figure 1/ Figura 1. Diazepam 
The official monographs of the Portuguese Pharmacopeia (2) state that diazepam tablets should contain not less than $90.0 \%$ and not more than $110.0 \%$ of the labelled amount of the active substance.

This laboratory experiment involves the quantification of $5 \mathrm{mg}$ diazepam tablets and makes use of a straightforward ultraviolet spectrophotometer usually available at the undergraduate laboratory. Students are provided with $5 \mathrm{mg}$ diazepam tablets and a stock solution of diazepam of known concentration, from which they prepare their pharmaceutical sample and the standard solutions of diazepam to construct a calibration curve. Sulphuric acid $5 \mathrm{~g} \mathrm{~L}^{-1}$ in methanol is used as the solvent for all the above solutions. A calibration curve is constructed by plotting the average absorbances of the standard solutions, which are assayed in triplicate, against their known concentrations. Regression analysis is used to determine the mass of diazepam in the prescription tablet. The value obtained is then compared with the manufacturer's claim and with the pharmacopeia's specifications. The entire laboratory procedure is completed in a single three-hour period.

\section{Materials and Methods}

\section{Apparatus and Reagents}

A Shimadzu UV-1603 ultraviolet-visible spectrophotometer and $1 \mathrm{~cm}$ length quartz cells of $3 \mathrm{~mL}$ volume were used. The operation temperature was kept constant at $25^{\circ} \mathrm{C}$ by means of a water bath. Commercial tablets of diazepam with labelled amount of $5 \mathrm{mg}$ were obtained from a local pharmacy.

\section{Preparation of Sample and Standard Solutions}

A diazepam solution was prepared by accurately weighing $10 \mathrm{mg}$ of the diazepam sample and dissolving it in a volumetric flask to $100 \mathrm{~mL}$, using sulphuric acid $5 \mathrm{~g}$ $\mathrm{L}^{-1}$ in methanol as the solvent. A $25 \mathrm{~mL}$ aliquot of this solution was taken and diluted in a volumetric flask to $250 \mathrm{~mL}$, using the same solvent, in order to prepare a stock solution of diazepam with a final concentration of $10.0 \mathrm{mg} \mathrm{mL}^{-1}$. Students were provided with both the diazepam stock solution and the solvent.

Serial dilutions from the stock solution of diazepam were performed, using the methanolic sulphuric acid solution as the solvent, to prepare standard solutions (usually $10 \mathrm{~mL}$ being generally sufficient) of the following concentrations: $2.0 \mathrm{mg} \mathrm{mL}^{-1}, 4.0 \mathrm{mg} \mathrm{mL}^{-1}, 6.0 \mathrm{mg}$ $\mathrm{mL}^{-1}$ and $8.0 \mathrm{mg} \mathrm{mL}^{-1}$. These solutions, including the stock solution of diazepam, were used as standards in the acquisition of the calibration curve data.
As monografias oficiais da Farmacopeia Portuguesa (2) mencionam que os comprimidos de diazepam não devem conter menos do que $90,0 \%$ e não mais do que 110,0 \% da quantidade indicada da substância activa.

Este trabalho laboratorial envolve a quantificação de comprimidos de $5 \mathrm{mg}$ de diazepam, recorrendo a um espectrofotómetro de ultravioleta simples, geralmente disponível no laboratório de aulas. São fornecidos aos alunos comprimidos com $5 \mathrm{mg}$ de diazepam e uma solução stock de diazepam de concentração conhecida, a partir do qual se preparam a amostra e as soluções padrão para construir uma curva de calibração. Para todas as soluções é utilizado ácido sulfúrico $5 \mathrm{~g} \mathrm{~L}^{-1}$ em metanol como solvente. A curva de calibração é construída representando as absorvâncias médias das soluções padrão, as quais são testadas em triplicado, contra as suas concentrações conhecidas. Por análise de regressão, determina-se a massa de diazepam no comprimido. $\mathrm{O}$ valor obtido é então comparado com a indicação do fabricante e com as especificações da Farmacopeia. Este procedimento laboratorial é completado num período de três horas.

\section{Materiais e Métodos}

\section{Equipamento e Reagentes}

Foi utilizado um espectrofotómetro ultravioleta-visível Shimadzu UV-1603 e células de quartzo com um centímetro de comprimento e de $3 \mathrm{~mL}$ de volume. A temperatura foi mantida constante a $25^{\circ} \mathrm{C}$ por meio de um banho de água. Os comprimidos de diazepam com dosagem de $5 \mathrm{mg}$ foram obtidos a partir de uma farmácia local.

\section{Preparação da amostra e das soluções-padrão}

Preparou-se uma solução diazepam por pesagem exacta de $10 \mathrm{mg}$ da amostra de diazepam e dissolução em balão volumétrico de $100 \mathrm{~mL}$, utilizando-se ácido sulfúrico a $5 \mathrm{~g} \mathrm{~L}^{-1}$ em metanol como solvente. Uma alíquota de $25 \mathrm{~mL}$ desta solução foi diluída num balão volumétrico de $250 \mathrm{~mL}$, utilizando o mesmo solvente, para preparar uma solução stock de diazepam com uma concentração final de $10,0 \mu \mathrm{g} \mathrm{mL}^{-1}$. Foram fornecidos aos estudantes tanto com a solução stock de diazepam como o solvente.

Foram realizadas diluições em série a partir da solução stock de diazepam, utilizando a solução de ácido sulfúrico em metanol como solvente, para preparar as soluções padrão (10 mL são geralmente suficiente) das seguintes concentrações: $2,0 \mu \mathrm{g} \mathrm{mL}^{-1}, 4,0 \mu \mathrm{g} \mathrm{mL}^{-1}$, $6,0 \mu \mathrm{g} \mathrm{mL} \mathrm{m}^{-1}$ e $8,0 \mu \mathrm{g} \mathrm{mL}^{-1}$. Estas soluções, incluindo a 
The preparation of the pharmaceutical sample was based on the assay described in the Portuguese Pharmacopeia (2) for diazepam tablets. A $5 \mathrm{mg}$ diazepam tablet was accurately weighed and crushed with a mortar and pestle. The powder was quantitatively dissolved in a volumetric flask to $100 \mathrm{~mL}$, using the same solvent employed in the preparation of the standard solutions. The solution was shaken for about 15 minutes and then filtered. A 1:10 dilution, performed by taking a $5 \mathrm{~mL}$ aliquot of this solution and diluting it to $50 \mathrm{~mL}$ in a volumetric flask, using the same solvent, produced the pharmaceutical sample to be analysed, with an expected diazepam concentration of $5.0 \mathrm{mg} \mathrm{mL}^{-1}$.

Care was taken to protect all the above solutions from light since diazepam is light sensitive.

Hazards: Diazepam is a central nervous system depressant and it is harmful when in contact with the skin and if swallowed. The sulphuric acid solution in methanol used as a solvent is toxic and highly flammable. Diazepam solutions must be handled with care. Students must wear suitable protective clothing, gloves and chemical safety goggles and avoid contact with eyes, skin and clothing.

\section{Ultraviolet Absorption Spectrum and Calibration Curve}

The ultraviolet absorption spectrum of the diazepam stock solution was registered between $400 \mathrm{~nm}$ and 200 $\mathrm{nm}$. The pure solvent was used as the reference blank. In all cases $1 \mathrm{~cm}$ length quartz cells were used, filled with $3.0 \mathrm{~mL}$ of the solution under analysis.

The absorption maximums of the diazepam stock solution occurred at the wavelengths of $365 \mathrm{~nm}, 284 \mathrm{~nm}$, $242 \mathrm{~nm}$ and $205 \mathrm{~nm}$ (Figure 2). Triplicate readings of the absorbance of each of the standard solutions were performed at the maximum wavelength of $242 \mathrm{~nm}$. The average absorbance of each standard solution of known concentration was calculated and the values used in the construction of the calibration curve, a plot of the absorbance as a function of concentration $\left(\mathrm{mg} \mathrm{mL}^{-1}\right)$. This was done with the aid of Microsoft Excel, as was the regression analysis.

\section{Quantitative Analysis of Diazepam Tablets}

The ultraviolet absorption spectrum of the pharmaceutical sample was registered between $400 \mathrm{~nm}$ and 200 $\mathrm{nm}$ (Figure 2). Triplicate readings of the absorbance of this solution were also obtained, at the same wavelength used for the analysis of the standard solutions.

The concentration of the solution was determined using the equation of the regression analysis obtained from the calibration curve. This value was multiplied by ten, which was the dilution factor, in order to determine the solução stock de diazepam, foram utilizadas como padrões para a aquisição dos dados da curva de calibração. A preparação da amostra foi baseada no ensaio descrito na Farmacopeia Portuguesa (2) para comprimidos de diazepam. Um comprimido de $5 \mathrm{mg}$ de diazepam foi rigorosamente pesado e triturado utilizando almofariz e pilão. O pó foi dissolvido num balão volumétrico de 100 ml, utilizando o mesmo solvente usado na preparação das soluções-padrão. A solução foi agitada durante cerca de 15 minutos e depois filtrada. Por fim procedeuse a uma diluição 1:10 de uma alíquota de $5 \mathrm{~mL}$ desta solução para $50 \mathrm{~mL}$ num balão volumétrico utilizando o mesmo solvente, obtendo-se assim a amostra a ser analisada, com uma concentração prevista de $5,0 \mu \mathrm{g} \mathrm{mL}^{-1}$ de diazepam.

Foi necessário ter o cuidado de proteger todas as soluções da luz, uma vez que o diazepam é sensível à luz.

Perigos: O diazepam é um depressor do sistema nervoso central e é nocivo quando em contacto com a pele e por ingestão. A solução de ácido sulfúrico em metanol usada como solvente é tóxica e altamente inflamável. As soluções de diazepam devem ser manuseadas com cuidado. Os estudantes devem usar bata, luvas e óculos de segurança e devem evitar o contato com os olhos, pele e roupas.

\section{Espectro de Absorção no Ultravioleta e Curva de Calibração}

O espectro de absorção no ultravioleta da solução stock de diazepam foi registado entre $400 \mathrm{~nm}$ e $200 \mathrm{~nm}$. O solvente puro foi usado como branco de referência. Em todos os casos, foram usadas células de quartzo de um centímetro de comprimento, contendo $3,0 \mathrm{~mL}$ da solução a ser analisada.

Os máximos de absorção da solução stock de diazepam ocorreram aos comprimentos de onda de $365 \mathrm{~nm}, 284$ $\mathrm{nm}, 242 \mathrm{~nm}$ e $205 \mathrm{~nm}$ (Figura 2). Foram realizadas leituras de absorvância em triplicado para cada uma das soluções-padrão, no comprimento de onda de $242 \mathrm{~nm}$. A absorvância média de cada solução padrão de concentração conhecida foi calculada e os valores foram utilizados na construção da curva de calibração, um gráfico da absorvância em função da concentração (mg $\mathrm{mL}^{-1}$ ). A curva de calibração foi feita com recurso ao Microsoft Excel, bem como a análise de regressão.

\section{Análise Quantitativa dos comprimidos de Diazepam}

O espectro de absorção no ultravioleta da amostra farmacêutica foi registado entre $400 \mathrm{~nm}$ e $200 \mathrm{~nm}$ (Figura 2). Foram obtidas leituras da absorvância desta solução em triplicado, no mesmo comprimento de onda utilizado para a análise das soluções-padrão. A concentração da solução foi determinada usando a equação da 
concentration of diazepam in the pharmaceutical sample in $\mathrm{mg} /$ tablet. This value was then compared with the manufacturer's claim and with the Portuguese Pharmacopeia specifications for diazepam tablets.

\section{Results and Discussion}

Students must obtain the ultraviolet absorption spectrum of diazepam in order to ascertain the wavelength of maximum absorbance. All absorbance readings should be performed at this wavelength, at which the sensitivity of the method is best. The stock solution of diazepam, with a concentration of $10.0 \mathrm{mg} \mu \mathrm{L}^{-1}$, was used for this purpose. The ultraviolet absorption spectrum of this standard solution is shown in Figure 2 (upper curve). There are four absorption peaks, at 365, 284, 242, and $205 \mathrm{~nm}$. regressão obtida a partir da curva de calibração. Este valor foi multiplicado por 10, o factor de diluição, a fim de determinar a concentração de diazepam na amostra farmacêutica em $\mathrm{mg} /$ comprimido. Este valor foi então comparado com o indicado na embalagem e com as especificações da Farmacopeia portuguesa para comprimidos diazepam (2).

\section{Resultados e Discussão}

Os estudantes devem obter o espectro de absorção no ultravioleta do diazepam, a fim de determinar o comprimento de onda de absorvância máxima. Todas as leituras de absorvância devem ser realizadas neste comprimento de onda, no qual a sensibilidade do método é melhor. A solução stock de diazepam, com concentração de 10,0 $\mathrm{mg} \mu \mathrm{L}^{-1}$, foi utilizada para este propósito. O espectro de absorção no ultravioleta desta solução padrão é mostrado na Figura 2 (curva superior). Observaram-se quatro picos de absorção, a $365 \mathrm{~nm}, 284 \mathrm{~nm}, 242 \mathrm{~nm}$ e $205 \mathrm{~nm}$.

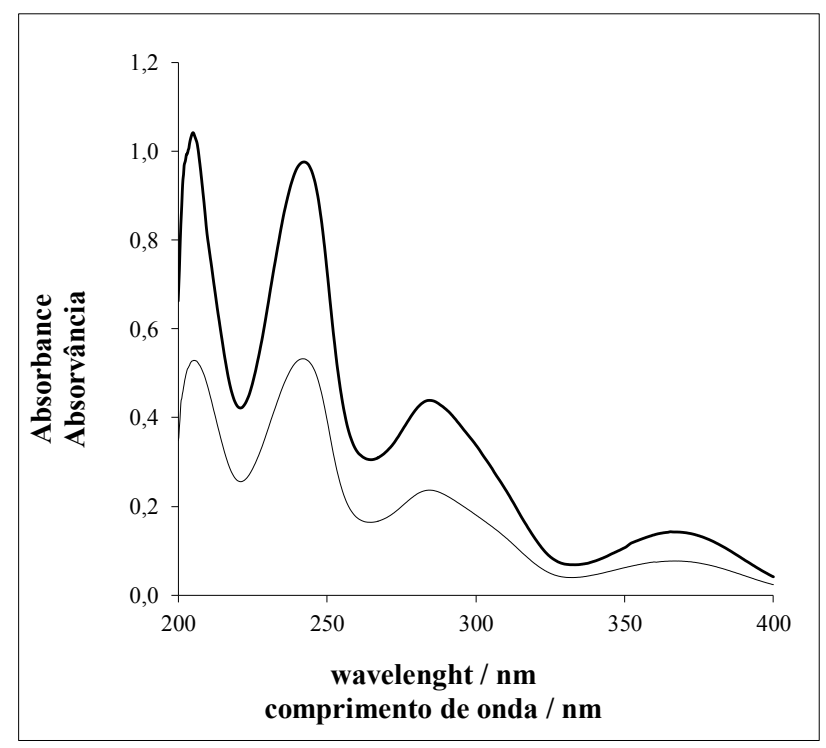

Figure 2. Ultraviolet absorption spectrum of a $10.0 \mu \mathrm{g} \mathrm{mL}^{-1}$ standard diazepam solution (upper curve) and a solution from a commercial sample of diazepam (lower curve).

Figura 2. Espectro de absorção no ultravioleta de uma solução padrão de diazepam a $10,0 \mu \mathrm{g} \mathrm{mL}^{-1}$ (curva superior) e de uma solução preparada a partir de uma amostra comercial de diazepam (curva inferior). 
The ultraviolet absorption spectrum of the commercial sample well-matched the one of the stock solution, ensuring that the pharmaceutical sample contained diazepam and that no interferences from excipients remained in the solution. This spectrum is shown in Figure 2 (lower curve). The average absorbances of each diazepam solution, at the wavelength of $242 \mathrm{~nm}$, are registered in Table 1.
O espectro de absorção no ultravioleta da amostra comercial também foi obtido e comparado com o da solução de stock, de modo a assegurar que a amostra farmacêutica continha o diazepam e que não houve interferência dos excipientes que eventualmente possam ter permanecido na solução. Este espectro é mostrado na Figura 2 (curva inferior). As absorvâncias médias de cada solução de diazepam, ao comprimento de onda de $242 \mathrm{~nm}$, estão registadas na tabela 1 .

Table 1. Absorbances (average of three readings) of diazepam solutions $(\lambda=242 \mathrm{~nm})$.

Tabela 1. Absorvâncias (média de três leituras) das soluções de diazepam $(\lambda=242$

$\mathrm{nm})$.

\begin{tabular}{ccccccc}
\hline $\begin{array}{c}\text { Concentration } \\
\text { Concentração / }\left(\mu \mathbf{g ~ m L}^{-1}\right)\end{array}$ & 2.00 & 4.00 & 6.00 & 8.00 & 10.0 & $\begin{array}{c}\text { Tablet } \\
\text { Comprimido }\end{array}$ \\
\hline $\begin{array}{c}\text { Absorbance } \\
\text { Absorvância }\end{array}$ & 0.216 & 0.407 & 0.612 & 0.821 & 1.013 & 0.526 \\
\hline
\end{tabular}

The standard calibration curve obtained (Figure 3) shows a linear relationship between absorbance and concentration in the $2.0 \mathrm{mg} \mathrm{mL}^{-1}$ to $10.0 \mathrm{mg} \mathrm{mL}^{-1}$ interval, indicating that the Lambert-Beer Law is obeyed within this range of concentrations.
A curva de calibração obtida (Figura 3) mostra uma relação linear entre a absorvância e a concentração no intervalo de 2,0 $\mathrm{mg} \mathrm{mL}^{-1}$ a $10,0 \mathrm{mg} \mathrm{mL}^{-1}$, demonstrando que a lei de Lambert-Beer é obedecida nesta gama de concentrações.

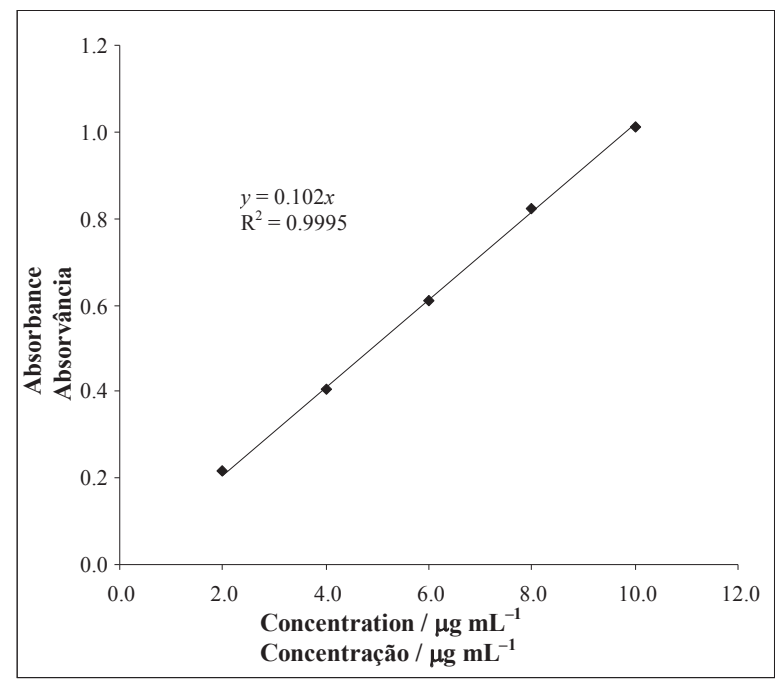

Figure 3. Standard calibration curve of diazepam obtained at the wavelength of $242 \mathrm{~nm}$.

Figura 3. Curva de calibração do diazepam, obtida ao comprimento de onda de $242 \mathrm{~nm}$. 
According to the calibration curve obtained, the concentration of the sample solution was determined as $5.16 \mathrm{mg} \mathrm{mL}^{-1}$. The mass of diazepam in the commercial tablet was determined to be $(5.16 \pm 0.01) \mathrm{mg}$. This value is within the tolerable and expected percentage range of the manufacturer's claim as set forth by the Portuguese Pharmacopeia (2).

There are several ways in which this experiment can be modified. Diazepam tablets are available in different formulations and any of these should give results in the linear range of the absorbance-concentration plot (Figure 3). Changing the commercial formulation from student to student allows them to quantitatively analyse different unknowns. Diazepam tablets of the same formulation but from different manufacturers can also be used. The experiment is also suited for the analysis of other benzodiazepines such as chlordiazepoxide or alprazolam.

The laboratory experiment described herein allows students to relate science and technology to everyday life and simultaneously demonstrates the qualitative and quantitative powers of ultraviolet spectroscopy. The use of a familiar drug, such as diazepam, for this purpose turns this experiment into an attractive and engaging one. The results obtained are clear and reproducible, making it easier for students to compare and evaluate their results.

\section{Acknowledgments}

This work is part of the laboratory course of Pharmaceutical Organic Chemistry, conducted by Prof ${ }^{a}$. Dr ${ }^{\mathrm{a}}$. Fátima Frazão, to whom this paper is dedicated.

\section{Conflict of interests}

The authors declare that there are no financial or personal relations that could be viewed as a potential conflict of interests.
De acordo com a curva de calibração obtida, a concentração da solução da amostra foi determinada como $5,16 \mathrm{mg} \mathrm{mL}^{-1}$. A massa de diazepam no comprimido comercial é então 5,16 $\pm 0,01 \mathrm{mg}$. Este valor está dentro da gama permitida e esperada de acordo com a indicação do fabricante e o estabelecido pela Farmacopeia Portuguesa.

Este trabalho laboratorial pode ser modificado de várias formas. Estão comercialmente disponíveis comprimidos de diazepam com diferentes formulações, sendo que qualquer um deles deverá dar resultados na região linear do gráfico absorvância-concentração (Figura 3). Alterando o tipo formulação de aluno para aluno permitirá analisar quantitativamente diferentes amostras. Poderão também utilizar-se comprimidos com o mesmo tipo de formulação, mas de diferentes fabricantes. Este procedimento pode também aplicar-se à análise de outras benzodiazepinas tais como clordiazepóxido e alprazolam.

O trabalho laboratorial descrito permite que os alunos relacionem a ciência e tecnologia com a vida real e, simultaneamente demonstra o interesse qualitativo e quantitativo da espectroscopia de ultravioleta. A utilização de um fármaco conhecido como o diazepam torna este trabalho atrativo e envolvente. Os resultados obtidos são claros e reprodutíveis, tornando mais fácil para os alunos a comparação entre os seus resultados.

\section{Agradecimentos}

Este trabalho faz parte da componente laboratorial da unidade curricular de Química Orgânica Farmacêutica, coordenada pela Prof. ${ }^{a}$ Dr. ${ }^{a}$ Fátima Frazão, a quem este artigo é dedicado.

\section{Conflito de interesses}

Os autores declaram que não existem relações financeiras ou pessoais que puderam ser vistas como um potencial conflito de interesses. 


\section{References / Referências}

(1) Hansen SH, Pedersen-Bjergaard S, Rasmussen KE. Introduction to pharmaceutical chemical analysis. Chichester:Wiley; 2012.

(2) Farmacopeia Portuguesa VII. $1^{\circ}$ vol. Lisboa:Instituto Nacional da Farmácia e do Medicamento; 2002.

(3) Byrd H, O'Donell SE. A general chemistry laboratory theme: spectroscopic analysis of aspirin. J Chem Educ 2003; 80:174-6.

(4) Aberásturi F, Jiménez AI, Jiménez F, Arias JJ. UV-visible first derivative spectrophotometry applied to an analysis of a vitamin mixture. J Chem Educ 2001; 78:793-5.

(5) Ribone, MÉ, Pagani AP, Olivieri AC, Goicoechea HC. Determination of the active principle in a syrup by spectrophotometry and principle component regression analysis. An advanced undergraduate experiment involving chemometrics. J Chem Educ 2000; 77:1330-3.
(6) McDevitt VL, Rodriguez A, Williams KR. Analysis of soft drinks: UV spectrophotometry, liquid chromatography, and capillary electrophoresis. J Chem Educ 1998; 75:625-8.

(7) Adams PE. Determining iron content in foods by spectrophotometry. J Chem Educ 1995; 72:649-51.

(8) Yarnelle MK, West KJ. Modification of an ultraviolet spectrophotometric determination of the active ingredients in APC tablets. J Chem Educ 1989; 66:601-2.

(9) Stolzberg RJ. Evaluation of derivative ultraviolet spectrometry for determining saccharin in cola and other matrices: an instrumental methods experiment. J Chem Educ 1986; 63:351-3.
(10) Van Atta RE. Ultraviolet spectrophotometric determination of caffeine in cola drinks: an organic analytical experiment. J Chem Educ 1979; 56:666

(11) Fernandez LTH, Klappmeier FH. Experiment for instrumental analysis. The determination of aspirin by ultraviolet absorption. J Chem Educ 1978; 55:266.

(12)Liu S. Central nervous system depressants. In: Beale Jr. JM, Block JH, editors. Wilson and Gisvold's textbook of organic medicinal and pharmaceutical chemistry. 12th ed., Lippincott; 2011 p. 443-469. 